\title{
EVALUATION OF NEW ANTI-NEOPLASTIC ACTIVE INGREDIENT IN VITRO
}

B. A. El-Fiky ${ }^{1}$, K. A. Halfawy ${ }^{1}$, M. I. El-Naggar ${ }^{2}$ and N. A. Gobba ${ }^{3}$

${ }^{1}$ Genetic Engineering\& Biotech., Institute, Menouf. Univ., Sadat City, Egypt

${ }^{2}$ Department of Forensic Medicine \& Toxic, Faculty of Medicine, Alex. Univ., Egypt

${ }^{3}$ Department of Pharm. \& Toxic, Faculty of Pharmacy, Misr Univ. for Science and Tech., Egypt

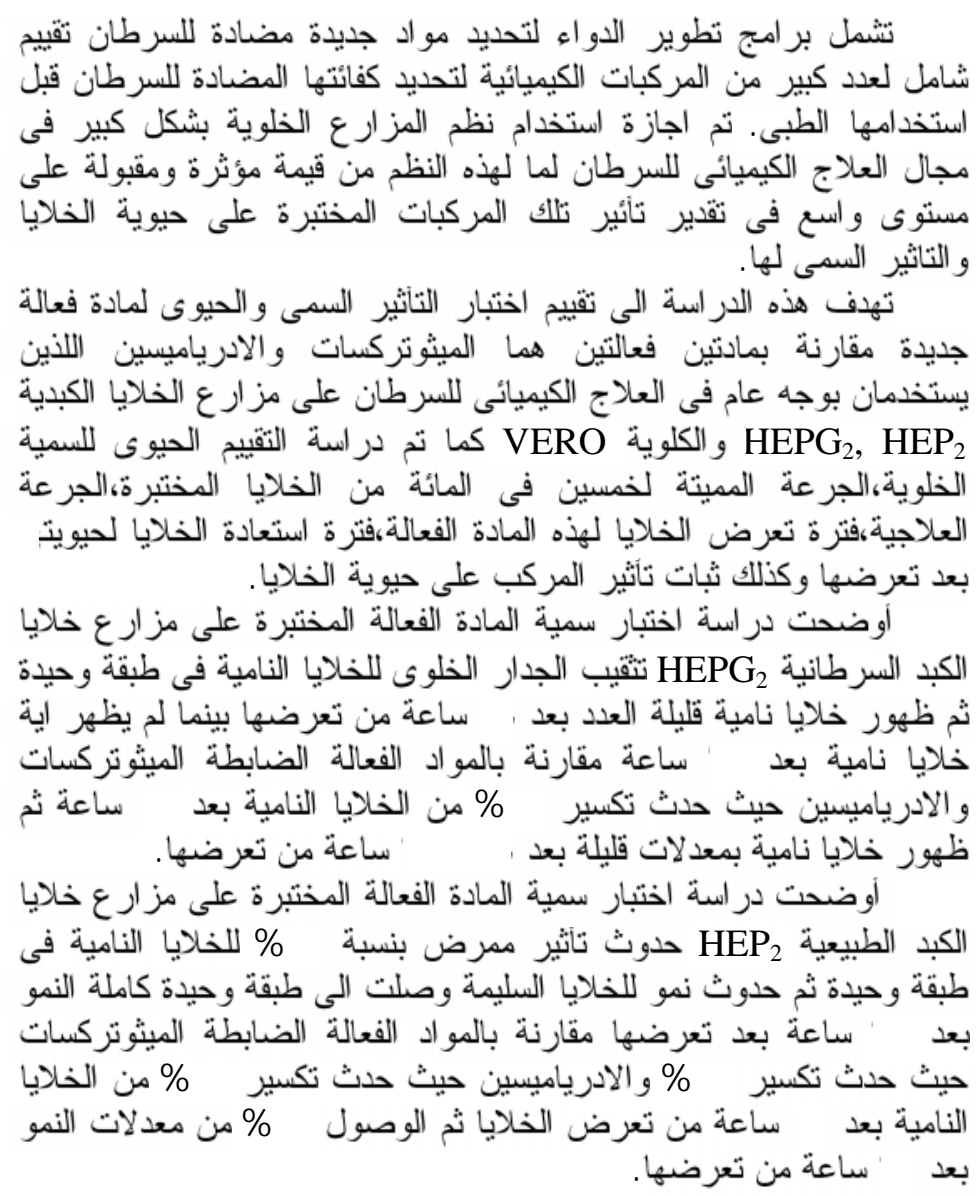




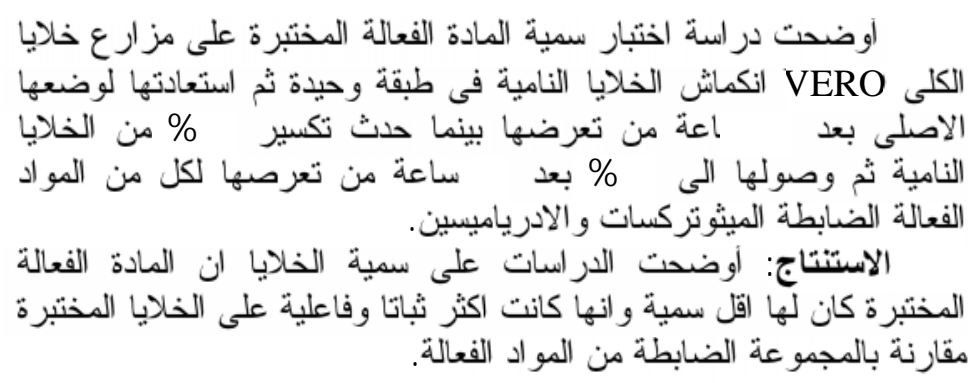

Drug development programs for identification of new antineoplastic agents involve extensive preclinical evaluation of vast numbers of chemicals for detection of anti-neoplastic activity. Cell culture systems have figured largely in the field of cancer chemotherapy, where the potential value of such systems for cytotoxicity and viability testing is now widely accepted.

The aim of this study is to evaluate cytotoxicity and viability testing of new anti-neoplastic active ingredient compared to Methotrexate and Adriamycin anti-neoplastic active ingredients which are commonly used for cancer chemotherapy on $H E P G_{2}$, $\mathrm{HEP}_{2}$ and $\mathrm{VERO}$ cell lines.

Cytotoxicity, LD50, therapeutic dose, drug exposure, recovery period and stability bioassay are determined.

Cytotoxicity bioassay of tested active ingredient on $\mathrm{HEPG}_{2}$ cells showed punching of all monolayer cells with few regenerative cells after $48 \mathrm{hr}$ and no regenerative cells after $72 \mathrm{hr}$ while Methotrexate and Adriamycin showed $75 \%$ cytopathic effect on monolayer cells after $24 \mathrm{hr}$ then cells begins to regenerate with few rate after 48-72 $h r$.

Cytotoxicity bioassay of tested active ingredient on $\mathrm{HEP}_{2}$ cells showed $25 \%$ cytopathic effect on monolayer cells then regenerated to reach complete monolayer after $72 \mathrm{hr}$ compared to Methotrexate $50 \%$ and Adriamycin 75\% cytopathic effect on monolayer cells then reached to $75 \%$ of monolayer after $72 \mathrm{hr}$.

Cytotoxicity of tested active ingredient onVero cells showed retraction of monolayer cells then retains its original pattern after $24 \mathrm{hr}$ of exposure while Methotrexate and Adriamycin showed destruction of more 50\% of monolayer cell population then reached to $75 \%$ of monolayer after $72 \mathrm{hr}$.

In conclusion; cytopathological studies showed that the tested active ingredient has low cytotoxicity, more stable and more telorated compared to controls. 


\section{INTRODUCTION}

The National Cancer Institute (NCI) now uses 60 human tumour cell lines to look for chemicals that might be effective against cancer. They use cancer cells from the colon, lung, skin,liver, kidney, ovary, brain and blood for their tests. In both the USA and the UK there are now human tissue banks where researchers can get normal and diseased tissue for testing ${ }^{1}$. Alternatively, researchers can buy many different human cell lines from commercial companies. The cells are grown in cell culture and the effect of various chemicals on their growth are studied. There are now more and more studies where human tumour cells are being used to study the effectiveness of different drugs for particular kinds of cancer, and also to work out the best dosage of these drugs ${ }^{2}$.

All of cell lines used in the present study was previously used for drug study, National Institute of Allergy and Infectious Diseases (NIAID) (2006), studied the safety, effectiveness, and side effects of an experimental bird flu vaccine grown in Vero cells at three different dosages $^{3}$. Béla Szende et $a l .^{4}$ studied the effect of simultaneous administration of Avemar and cytostatic drugs on viability of Vero cell cultures. Michael et al. ${ }^{5}$, studied antiviral and anticancer activity of Organotin polymers and reactants derived from Norfloxacin and
Ampicillin on Vero cells. Sujata et $a l^{6}$, studied apoptotic signaling induced by Tiazofurinan in vitro study on $\mathrm{Hep}_{2}$ cells. Zhai et al. ${ }^{7}$ studied development and characterization of multi-drug resistant on human hepatocarcinoma cell line $\left(\mathrm{HepG}_{2}\right)$ in nude mice.

\section{MATERIALS AND METHODS}

All methods used in the present study are modified from Freshney ${ }^{8}$.

\section{Cell lines}

$\mathrm{HEPG}_{2}, \mathrm{HEP}_{2}$ and Vero cell lines are cryopreserved in liquid nitrogen $\left(-196^{\circ} \mathrm{C}\right)$ cell bank at Animal Cell Culture Lab., Ainimal Biotechnology Department, Genetic Engineering and Biotechnology Institute, Sadat City, Minufiya University.

\section{RPMI 1640 growth medium}

For preparation of one liter; 10 gm of medium powder is added to $900 \mathrm{ml}$ deionized water, dissolved by magnetic stirrer at room temperature, after complete dissolving, penicillin (100 units/ $\mathrm{ml})$, streptomycin $(100 \mu \mathrm{g} / \mathrm{ml})$, and L-glutamine $(2 \mathrm{mM})$ were added, $\mathrm{pH}$ of the medium is adjusted by $1 \mathrm{~N}$ $\mathrm{NaOH}, 1 \mathrm{~N} \mathrm{HCl}$ to $\mathrm{pH}=7.7$ then volume is completed to $1000 \mathrm{ml}$ and sterilized by filtration through 0.22 . $\mu 1$ filter paper under sterile conditions. 
Fetal bovine serum (FBS)

Inactivated at $65^{\circ} \mathrm{C}$ water bath for $30 \mathrm{~min}$.

\section{Typsin enzyme}

The proteolytic enzyme is used at 1:250 dilution, $\mathrm{pH}=7.7$ for cell harvesting.

\section{Active ingredients}

Tested active ingredient, Methotrexate and Adriamycin.

\section{Thawing and cell propagation}

1- Cryopreseved tubes of cell lines are separately transferred quickly from liqiud nitrogen to $37^{\circ} \mathrm{C}$ water bath, cryopreserved cells are completely thawed within 3-5 min, tubes are swabed with $70 \%$ ethanol, transferred under sterile area of lamiar flow cabinet,cells are collected into $12 \mathrm{ml}$ sterile centrifuge tubes with screw caps,centrifugated at 1000 RPM for $10 \mathrm{~min}$.

2- Supernatent are aspirated off and the pellets are resuspended in prewarmed fresh RPMI 1640 growth medium,cell viability is tested with $0.4 \%$ trypan blue vital stain and counted with hemocytometer.

3- Cells are seeded at a concentration of $3 \times 10^{6}$ cells in $75 \mathrm{~cm}^{3}$ cell culture flasks with vented caps and incubated in $\mathrm{CO}_{2}$ incubator at $37^{\circ} \mathrm{C}$ for $24 \mathrm{hr}$ to reach monolayer then, the growth medium is aspirated off and replaced with fresh medium.
Lethal Dose (LD50) and Cytopathic effect Determination Protocol

1- Cells are harvested at the log. phase of growth as follows:

a- Cell culture flasks are examined under inverted microscope for cell viabilty and log. phase of growth.

b- Growth medium is aspirated off using sterile pipette, then 5-7 $\mathrm{ml}$ of trypsin enzyme pre-warmed at $37^{\circ} \mathrm{C}$ water bath is added to each cell culture flask, cells are incubated at $37^{\circ} \mathrm{C}$ for 10 min. in $\mathrm{CO}_{2}$ incubator.

c- Cell culture flasks are examined under inverted microscope for cell detachment, trypsin enzyme is deactivated by adding equal amount of RPMI 1640 growth medium suplemented with $10 \%$ FBS.

d- Cells are collected in sterile $12 \mathrm{ml}$ centrifuge tubes with screw caps and centrifugated at 1000 RPM for 10 minutes.

e- Supernatent is aspirated off and cell pellets are resuspended in growth medium, viability of cells is tested with $0.4 \%$ trypan blue vital stain and counted using hemocytometer.

2- Cells are resuspended at concentration of $2 \times 10^{5}$ cells $/ \mathrm{ml}$ growth medium supplemen-ted with $10 \%$ FCS for $\mathrm{Hep}_{2}$,Vero 
cells and $1.5 \times 10^{5}$ cells / $\mathrm{ml}$ for $\mathrm{HEPG}_{2}$.

3- Cells are seeded in 96-well microtiter plates $(100 \mu \mathrm{l} /$ well $)$ and incubated at $37^{\circ} \mathrm{C} \quad \mathrm{CO}_{2}$ incubator for $24 \mathrm{hr}$ to reach complete monolayer.

4- Growth medium is aspirated off and $100 \mu \mathrm{l}$ RPMI 1640 growth medium supplemented with $2 \%$ FCS/well is added to each well of microtiter plates.

5- Active ingredients are diluted to reach $1 \mathrm{X}$ concentration then,
$100 \mu \mathrm{l}$ of tested active ingredient was added to wells no $\mathrm{A}, \mathrm{B}$, standard drug no. 1 (Methotrexate) was added to wells no $\mathrm{C}, \mathrm{D}$, standard drug no. 2 (Adriblastina) was added to wells no E,F. G,H wells used as control. Serial dilution of tested drug are made in triplicate, Wells containing no drugs were used as controls (Fig. 1). Titer plates are incubated at $37^{\circ} \mathrm{C}$ for $24 \mathrm{~h}$, to investigate LD50 dose, cytopathic effect.

\section{Tested active ingredient \\ $(\mathbf{A}, \mathbf{B})$
Methotrexate active ingredient (C,D) Adriamycin active ingredient (E,F) Control}

$(\mathbf{G}, \mathbf{H})$

\begin{tabular}{|l|l|l|l|l|l|l|l|l|l|l|l|l||}
\hline & 1 & $\mathbf{2}$ & $\mathbf{3}$ & $\mathbf{4}$ & $\mathbf{5}$ & $\mathbf{6}$ & $\mathbf{7}$ & $\mathbf{8}$ & $\mathbf{9}$ & $\mathbf{1 0}$ & $\mathbf{1 1}$ & $\mathbf{1 2}$ \\
\hline A & & & & & & & & & & & & \\
\hline B & & & & & & & & & & & & \\
\hline C & & & & & & & & & & & & \\
\hline D & & & & & & & & & & & & \\
\hline E & & & & & & & & & & & & \\
\hline F & & & & & & & & & & & & \\
\hline G & \multicolumn{10}{|c||}{ Control } \\
\hline H &
\end{tabular}

Fig. 1: Microtiter plate showing active ingredients titration bioassay. 


\section{Drug exposure and drug duration bioassay \\ Protocol}

1- Cells are harvested at the log. phase of growth as described above.

2- Harvested cells are resuspended at $3.5 \times 10^{5}$ cells $/ \mathrm{ml}$ RPMI 1640 supplemented with $10 \%$ FCS. growth medium for $\mathrm{HEP}_{2}$, Vero cells and $3 \times 10^{5}$ cells $/ \mathrm{ml}$ for $\mathrm{HEPG}_{2}$ cells and, and seeded in $3.5 \mathrm{~cm}^{3}$ cell culture plates, incubated at $37^{\circ} \mathrm{C}$ for $24 \mathrm{hr}$ to reach complete monolayer, incubated in $\mathrm{CO}_{2}$ incubator at $37^{\circ} \mathrm{C}$ for $24 \mathrm{hr}$ to reach complete monolayer.

3- $200 \mu \mathrm{l}$ of pre-determined therapeutic dose concentration of active ingredients are added to cell culture growth medium, culture plates containing no active ingredients are used as control (Fig. 2). Cell culture plates are incubated in $\mathrm{CO}_{2}$ at $37^{\circ} \mathrm{C}$ for $24 \mathrm{~h}, 48 \mathrm{~h}, 72 \mathrm{~h}$, to investigate drug exposure and drug duration.

\section{Recovery period and bioassay \\ Protocol}

1- Cells are harvested at the log. phase of growth as described above.

2- Harvested cells are resuspended at $3.5 \times 10^{5}$ cells $/ \mathrm{ml}$ RPMI 1640 supplemented with $10 \%$ FCS growth medium for $\mathrm{HEP}_{2}, 3 \times 10^{5}$ cells $/ \mathrm{ml}$ for $\mathrm{HEPG}_{2}$ and Vero cells. The resuspended cells are seeded in $3.5 \mathrm{~cm}^{3}$ cell culture plates, incubated in $\mathrm{CO}_{2}$ incubator at $37^{\circ} \mathrm{C}$ for $24 \mathrm{hr}$ to reach complete monolayer.

3- $200 \mu \mathrm{l}$ of therapeutic dose concentration of active ingredients are added to cell culture growth medium, culture plates containing no active ingredient are used as control (Fig. 2). Cell culture plates are incubated in $\mathrm{CO}_{2}$ at $37^{\circ} \mathrm{C}$ for 24 $\mathrm{h}, 48 \mathrm{~h}, 27 \mathrm{~h}$, to investigate drug exposure and drug duration. Cell culture plates are incubated in $\mathrm{CO}_{2}$ incubator at $37^{\circ} \mathrm{C}$ for 24 $\mathrm{h}$, growth medium was renewed and incubated for 7 days in which growth medium was renewed every 2 days to investigate drug stability and recovery period. 
Cell Culture Plate: $\quad \begin{array}{lllll}1 & 2 & 3 & 4 & 5\end{array}$

HEPG2 Cells: Methotrexate active ingredient

Adriamycin active ingredient

Tested active ingredient

HEP2 Cells: Methotrexate active ingredient

Adriamycin active ingredient

Tested active ingredient

VERO Cells: Methotrexate active ingredient

Adriamycin active ingredient

Tested active ingredient

Fig. 2: Scheme for active ingredients exposure bioassay, plates 1,2,3,4 are titerated with LD50 lethal doses, plate 5 serves as control.

\section{RESULTS}

\section{In vitro study}

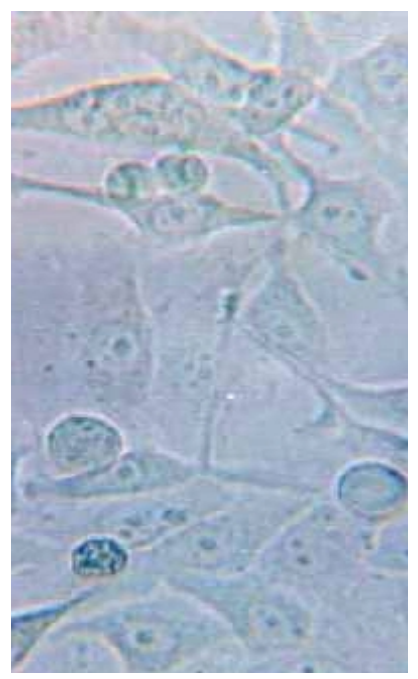

$\mathbf{a}$

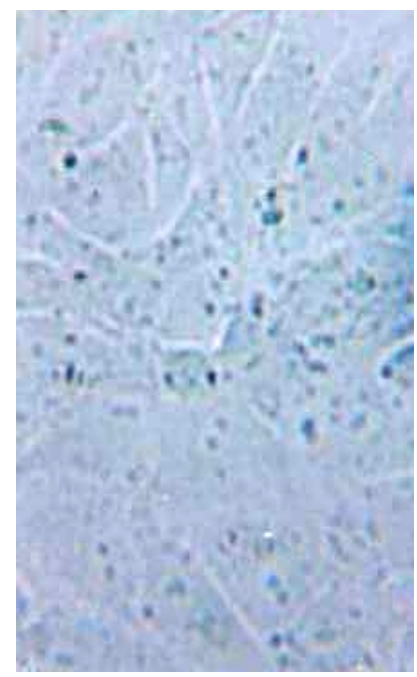

b

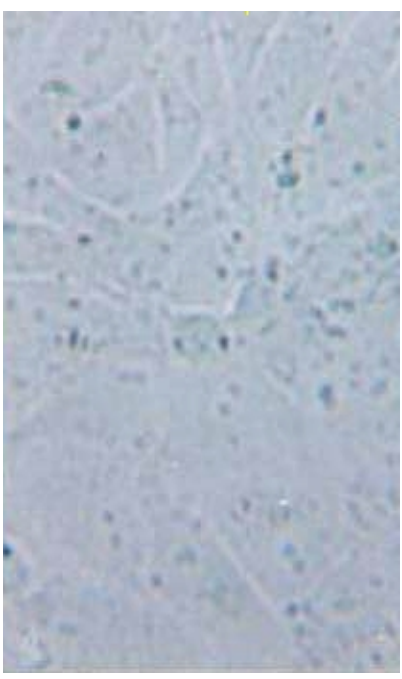

c

Fig. 3a,b,c: $\mathrm{HEP}_{2}$ cell line control. 


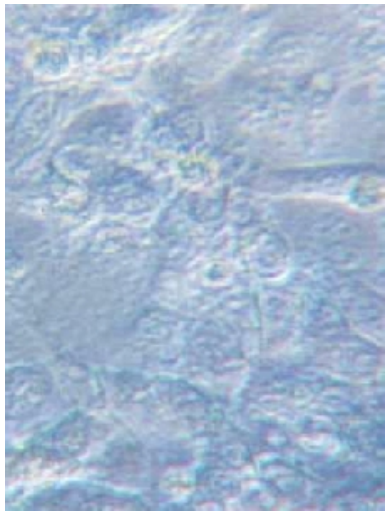

$\mathbf{a}$

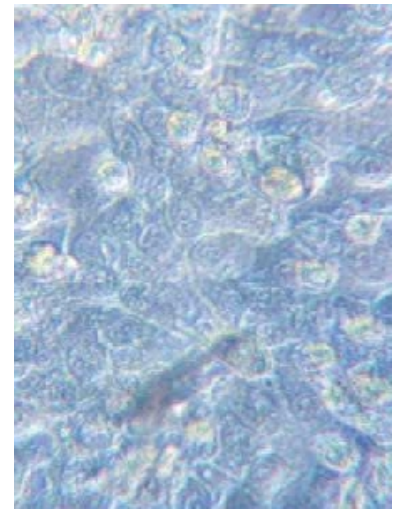

b

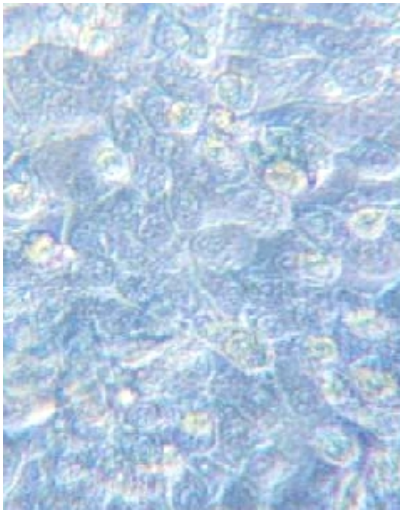

c

Fig. 4a,b,c: $\mathrm{Hep}_{2}$ cells treated with tested active ingredient for $24,48,72 \mathrm{hr}$ showing $25 \%$ cytopathic effect (a), regenerated cells are seen after $48 \mathrm{hrs}$ of exposure (b) and reached to complete monolayer (c) after $72 \mathrm{hr}$ of exposure.

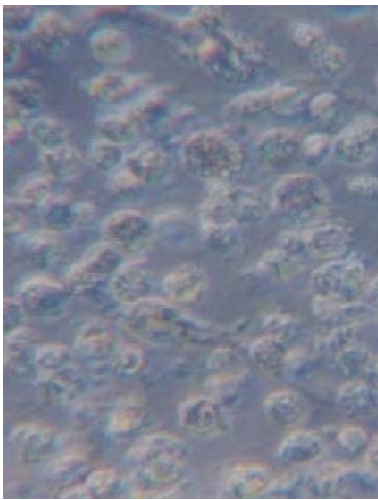

a

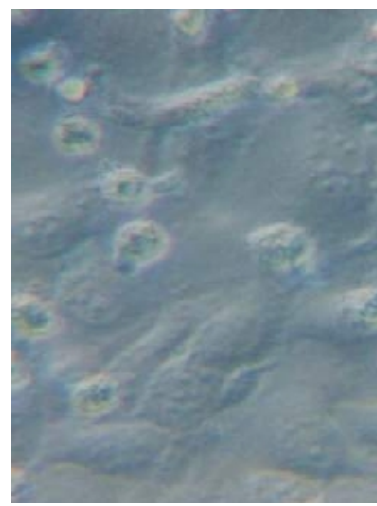

b

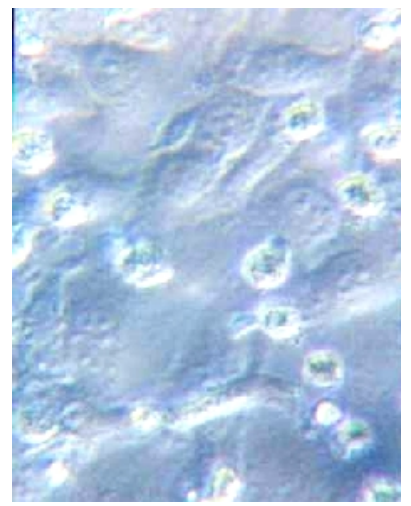

c

Fig. 5a,b,c: $\mathrm{Hep}_{2}$ cell line cell treated with Methotrexate active ingredient for $24,48,72 \mathrm{hr}$ exposure showing 50\% cytopathic effect (a), regenerated cells are seen after $48 \mathrm{hr}$ of exposure (b) and reached to $75 \%$ of monolayer cell population after $72 \mathrm{hr}$ of exposure (c). 


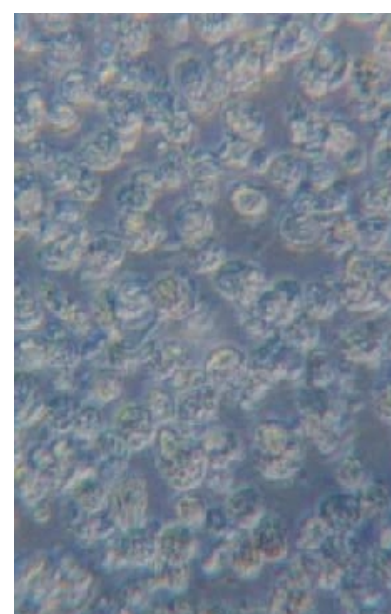

$\mathbf{a}$

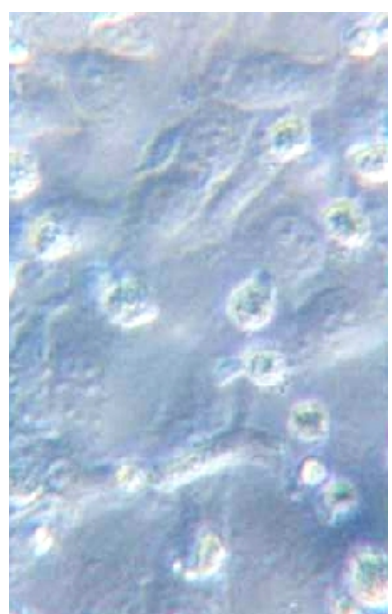

b

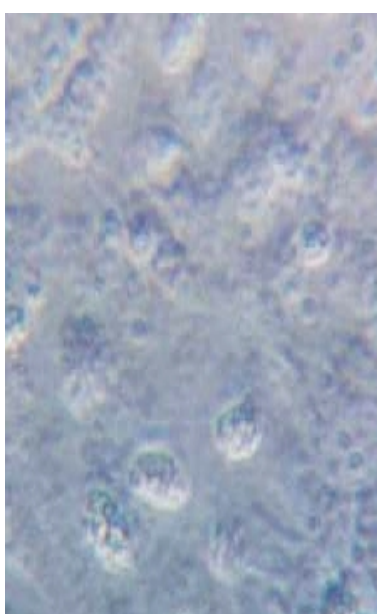

c

Fig. 6a,b,c: $\mathrm{Hep}_{2}$ cells treated with Adriamycin active ingredient for 24, 48, $72 \mathrm{hr}$ showing $50 \%$ cytopathic effect (a), regenerated cells are seen after $48 \mathrm{hrs}$ of exposure (b) and reached to $75 \%$ of monolayer cell population after $72 \mathrm{hr}$ of exposure (c).

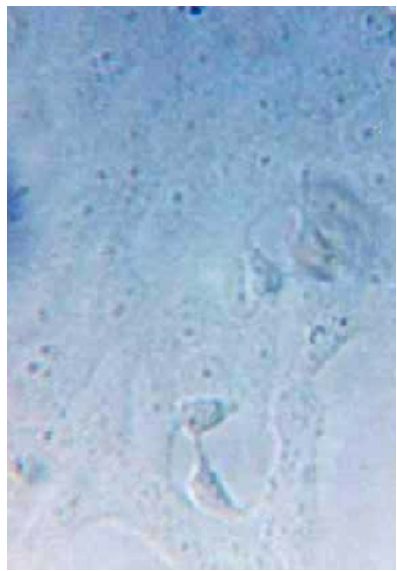

a

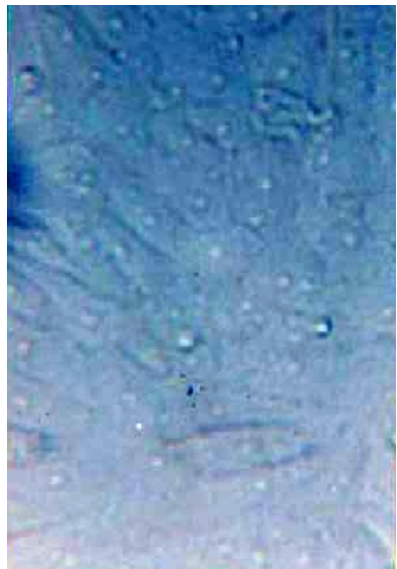

b

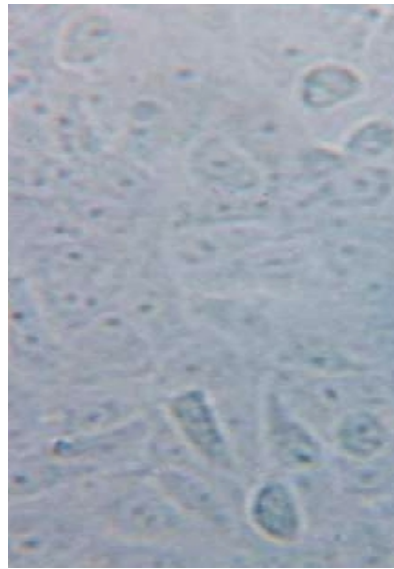

c

Fig. 7a,b,c: $\mathrm{HepG}_{2}$ cell line control. 


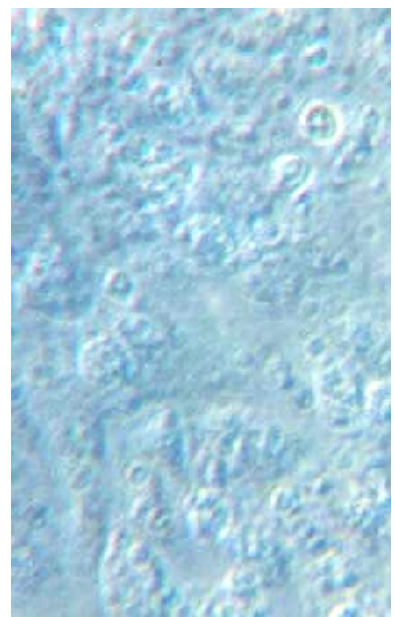

a

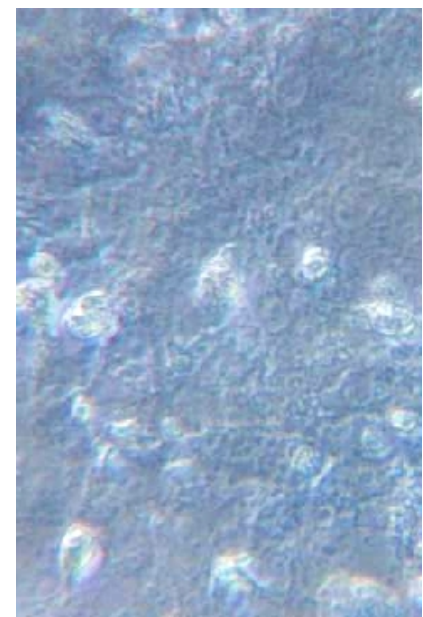

b

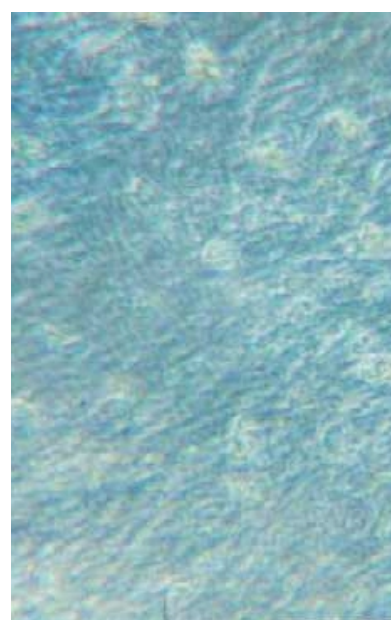

c

Fig. 8a,b,c: $\mathrm{HepG}_{2}$ cells treated with tested active ingredient for $24,48,72$ hr showing punching of all cell poulation (a), few number of regenerated cells are seen after $48 \mathrm{hr}$ of exposure (b) and no regenerated cell population are seen after $72 \mathrm{hr}$ of exposure (c).

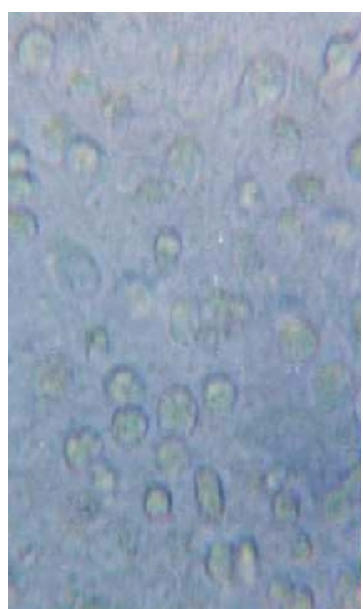

$\mathbf{a}$

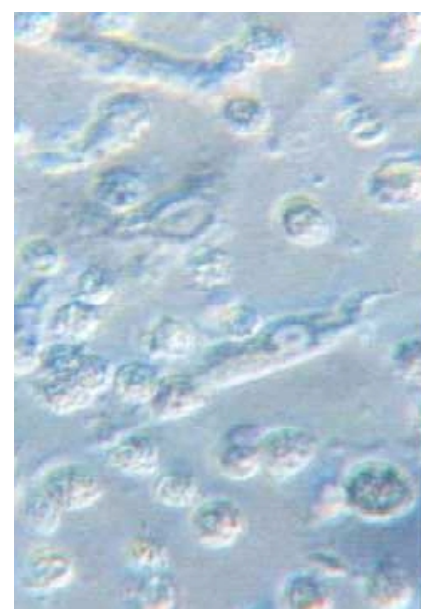

b

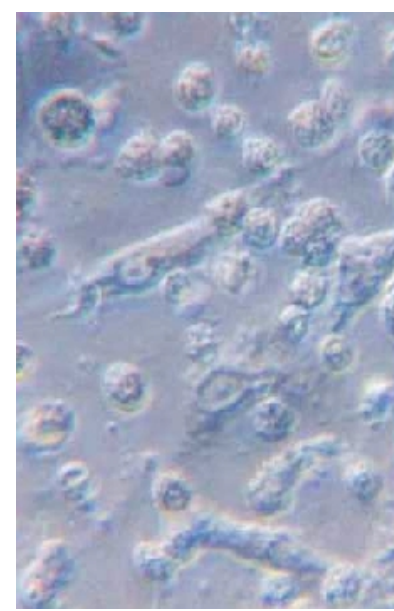

c

Fig. 9a,b,c: $\mathrm{HepG}_{2}$ cell line treated with Methotrexate active ingredient 24, $48,72 \mathrm{hr}$ showing detachment and death of more than $75 \%$ of monolayer cell population (a), few monolayer cells are seen after $48 \mathrm{hr}$ (b) and $72 \mathrm{hr}$ of exposure (c). 


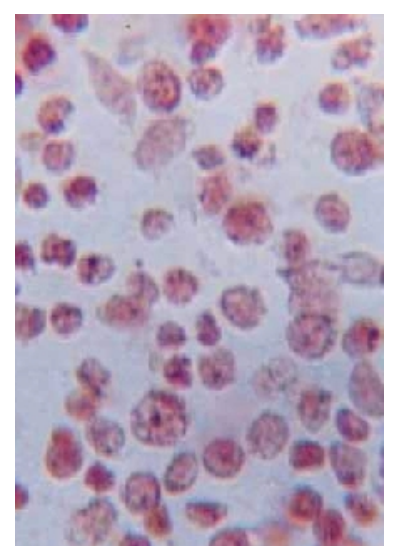

a

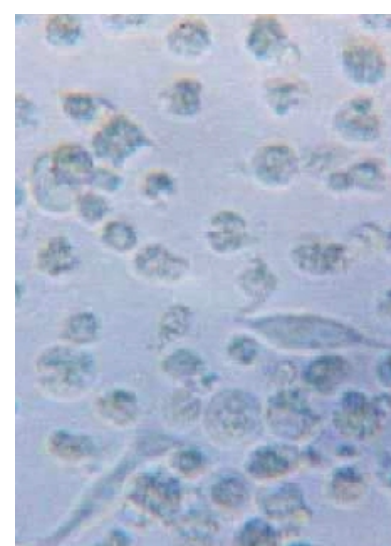

b

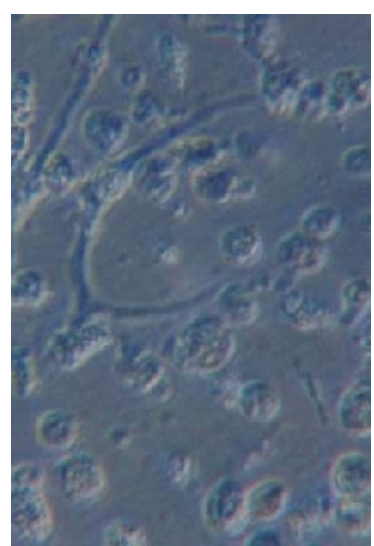

c

Fig. 10a,b,c: $\mathrm{HepG}_{2}$ cell line treated with Adriamycin active ingredient for $24,48,72 \mathrm{hr}$ showing detachment and death of more than $75 \%$ of monolayer cell population (a), few monolayer cells are seen after $48 \mathrm{hr}$ (b) and $72 \mathrm{hr}(\mathrm{c})$.

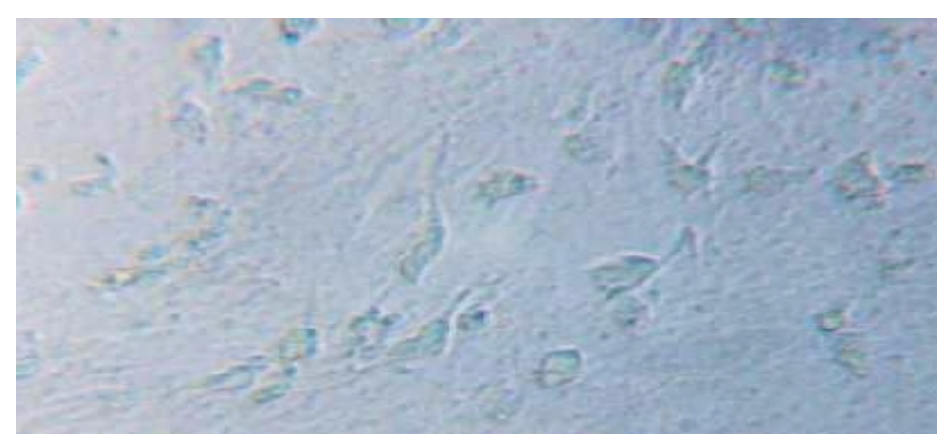

Fig. 11: Vero cell line control.

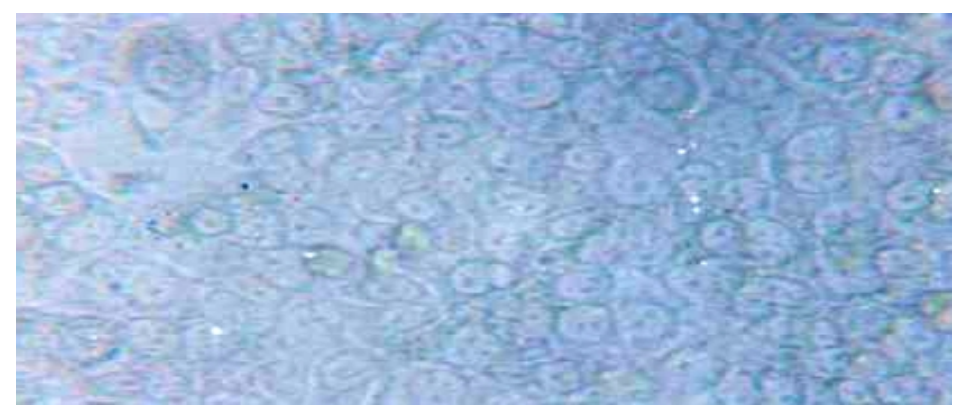

Fig. 12: Vero cells treated with tested active ingredient for $24 \mathrm{hr}$ showing retraction of monolayer cells after drug exposure then cell monolayer retain its original pattern after $24 \mathrm{hr}$ of exposure. 


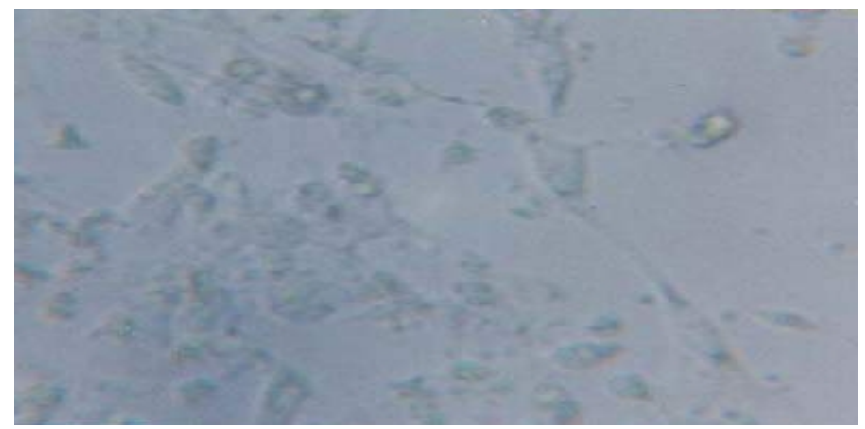

Fig. 13: Vero cell line treated with Methotrexate active ingredient for $24 \mathrm{hr}$ showing destruction of more than $50 \%$ of monolayer cell population.

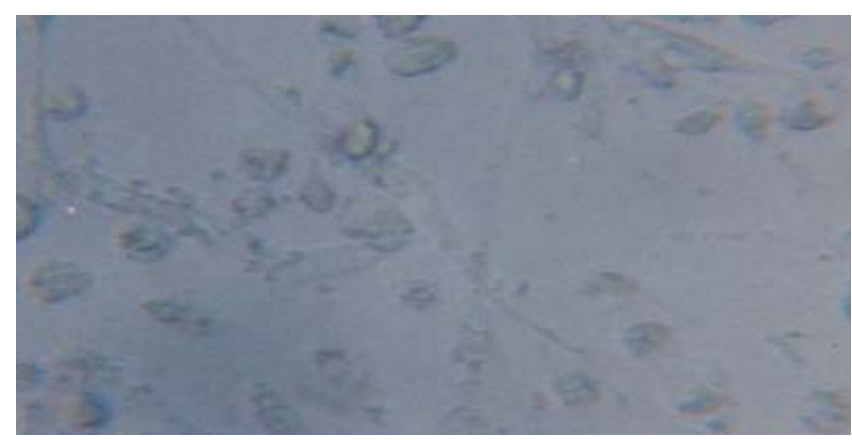

Fig. 14: Vero cell line treated with Adriamycin active ingredient $24 \mathrm{hr}$ showing destruction of more than $50 \%$ of monolayer cell population.

Table 1: Summary of results carried out in animal cell culture.

\begin{tabular}{|l|c|c|c|}
\hline \multicolumn{1}{|c|}{$\begin{array}{c}\text { Tested } \\
\text { Parameters }\end{array}$} & $\begin{array}{c}\text { Tested active } \\
\text { ingredient } \\
\text { treated group }\end{array}$ & $\begin{array}{c}\text { Methotrexate active } \\
\text { ingredient treated } \\
\text { group }\end{array}$ & $\begin{array}{c}\text { Adriamycin active } \\
\text { ingredient treated } \\
\text { group }\end{array}$ \\
\hline Lethal Dose & $1.0 \%$ & $0.01 \%$ & $0.01 \%$ \\
\hline Cytopathic effect & $25 \%$ & $\% 50 \%$ & $50 \%$ \\
\hline Drug exposure/hr & 72 & 48 & 24 \\
\hline Drug duration/day & 7 & 3 & 3 \\
\hline Efficacy & +++ & ++ & ++ \\
\hline Drug Stability & Stable & Not more than 3 days & Not more than 3 days \\
\hline Sterility & $\begin{array}{c}\text { Sterile without } \\
\text { filtration }\end{array}$ & Sterile & Sterile \\
\hline \hline
\end{tabular}

L.D. $=$ Low (Therapeutic) Dose. $\quad$ M.D. $=$ Moderate (Lethal) Dose H.D. $=$ High (Acute) dose. 


\section{DISCUSSION}

The development of new anticancer medicines requires the co-ordinated efforts of teams of scientists from all manner of chemical and biological sciences. The big issue that must be solved is selectivity; because cancer cells are just normal cells whose growth mechanisms have run amok, deliberately and precisely targeting them for destruction without harming the similar healthy cells remains a challenging task. Nevertheless, many exploitable differences distinguish cancer cells from their non-cancerous siblings, and these differences become the focal point of efforts to develop effective anticancer agents. Whereas a detailed discussion of the biochemical basis for this divergence is beyond the scope of this article, it is worth noting that differences in blood supply, oxygen content, DNA access and chemical signaling pathways, among many other factors, have been identified and exploited in this regard ${ }^{9}$. Fortunately, this wide range of different behaviors/characteristics between cancerous and healthy cells ensures that there is more than one way to attack the problem of selective cytotoxicity, so many different types of molecules can be explored for their ability to act as cancer cytotoxins.Any potential cancer chemotherapeutic candidate must undergo a rigorous series of tests prior to gaining FDA approval for commercialization. The process typically starts with the basic question of whether the molecule will, in fact, kill cancer cells. These types of assays are commonly performed in vitro against a panel of different types of cancer cells. In addition, ome mechanisms by which molecules might kill cancer cells are indirect, so additional testing in whole animal may be conducted as well. Success at this level then leads to further in vitro testing of toxicity against normal cell lines, etc. The results of preclinical trials with anticancer agents are commonly given as $\mathrm{ED}_{50}$ values, which is the effective dose that kills $50 \%$ of the cancer cells. The smaller the $\mathrm{ED}_{50}$, the lower the concentration of compound necessary to cause cancer cell death, and the more likely that the molecule will remain on track for further evaluation. It is unlikely that the molecule will be selective enough for its biological target, compared to other possible interaction sites, to remain a viable chemotherapeutic candidate. A molecule becomes a candidate for testing in humans if it displays both toxicity against cancer cells and is tolerated by healthy cells/whole animals ${ }^{10}$. Human testing is tightly regulated for ethical reasons and follows a three-phase protocol. Initially, Phase I tests are conducted. These tests involve treatment of a small number of 
healthy (paid) volunteers with the drug candidate in order to ascertain whether humans tolerate the compound. If no adverse effects are detected, then Phase II trials can commence. This part of the drug validation process recruits a small number of patients with different cancers that did not respond to other treatments ${ }^{11}$. Overwhelming success is not expected, because these cancers are typically refractory and beyond conventional treatment. Nevertheless, any sign of improvement is encouraging, even if the cancer is not destroyed. Drug candidates that continue to show therapeutic potential at this point then enter Phase III trials, in which they are administered to a broad range of cancer patients. Dosing schedules, long-term tolerance and therapeutic efficacy are determined during these trials, which can be quite lengthy. Eventually, if the drug candidate survives these experimental challenges, the compiled data are presented to the FDA for evaluation. Approval from the FDA for commercial sale then leads to a new anticancer drug on the market. While these human tests are ongoing, important issues involving pharmacokinetics, drug delivery methods, allergic reactions, etc. are investigated as well. The FDA does not play a passive role in this testing process; rather, it closely monitors progress with the intent of "fast-tracking" to market any promising candidates. Some very thorny issues, such as placebo usage to validate the trials, arise as potentially life-saving drugs are subjected to these lengthy experiments, and many pressures come to bear on the process from medical practitioners, patients and the drug's developer, typically a large pharmaceutical firm ${ }^{12}$.

\section{REFERENCES}

1- J. Liebman, British Journal of Cancer, 68, 1104 (1993).

2- National Cancer Institute, Screening and Prevention of Digestive Cancer-January (2002).

3- National Institute of Allergy and Infectious Diseases (NIAID) (2006).

4- S. Béla, M. Zolt, K. Zsuzsanna and T. Anna, Cancer Biotherapy \& RadioPharmaceuticals, 19, 1 (2004).

5- R. R. Michael, E. Charles, J. R. B. Carraher, L. R. Joanne and B. Kellyd, J. Polym. Mater, 23, 153 (2006).

6- P. Sujata, S. Himani, S. Chandresh, Hiremagalur and S. Neeta, Gene Ther. Mol. Biol., 10, 199 (2006).

7- B. J. Zhai, Z. Y. Shao, C. L. Zhao, $\mathrm{Hu} \mathrm{K}$. and F. Wu, World J. Gastroenterol., 12, 6614 (2006).

8- R. I. Freshney, Culture of animal cells, a Manual of Basic Technique, $5^{\text {th }}$ Ed.Hoboken NJ, John Wiley \& Sons (2005). 
9- B. Ekwall and B. Ekwall, Updated results from the final MEIC evaluation, Paper for the 15th annual Scandinavian Society for Cell Toxicology workshop, Denmark (1997).

10- N. Vahdati-Mashhadian, J. M. Reza and A. Nosrati, Pharmacology online, 3, 405 (2007).
11- J. J. Xu, D. Diaz, P. J. O'Brian, Chem. Biol. Interact., 150, 115 (2004).

12- B. Hileman, Many Doubt the $\$ 800$ Million Pharmaceutical Price Tag. Chemical and Engineering News, June 19 issue, 2006, p. 50. 